\title{
Tactical urbanism or revitalization - a city tailored for the people
}

\author{
Dariusz Gaweł \\ https://orcid.org/0000-0001-5759-1962 \\ d.gawel@pollub.pl \\ Department of Contemporary Architecture, Lublin University of Technology
}

\begin{abstract}
We live in the conditions of constantly changing cities. Spatial transformations taking place before our eyes concern both older districts, housing estates as well as technical infrastructure or non-urbanized areas. The participation of social organizations and the inhabitants themselves is very important for the success of the entire change process. So far, revitalization has been the most popular process of renewal in Poland. In recent years in many degrading cities of the world, tactical urban projects have proved to be a particularly popular and effective process of transforming public space. This article is an attempt to compare both processes in selected cities, taking into account the benefits of implementing them.
\end{abstract}

Keywords: tactical urbanism, city revitalization, city, people

\section{Introduction}

The aim of the article is to try to give a detailed view of the processes related to the formation of the phenomenon of tactical urban development, and compare its effects with experiences in Polish cities where revitalization was implemented. The article is a result of research carried out by the author in the subject of creating new public spaces and shaping contemporary urban-forming trends in the conditions of globalization. In his research (through literature criticism and field research "in situ"), the author performs a comparative analysis of urban space renovation processes in selected cities, assessing their impact on creating a built environment and living conditions of society.

\section{Modern problems of urban development}

For many, the city is seen as an ideal environment for living and easy functioning in the modern world. The blurring of the boundaries between the standard of living in urbanized and non-urbanized conditions is the result of ever-increasing technical progress and the development of new technologies. However, this does not change the fact that contemporary urbanization processes are becoming more and more violent and spontaneous. This can be partially explained by the rapid development of cities and the possibilities of people easily increasing their incomes. Processes of this type of transformations cumulating too quickly can prove dangerous. They lead to the stratification of society and being lost in new, different conditions. Social phenomena translate into the organization of life of residents in a very direct way and, consequently, influence the creation and management of urban space.

This is reflected in the diagnosed urban phenomena, characterized and described by:

- social (exclusion of many groups, unemployment, and consequently impoverishment of inhabitants) as well as spatial degradation of significant areas, sometimes even whole districts. Creating dangerous and risk-conducive enclaves (areas) on city maps significantly reduces living standards, while generating 
areas with no social and technical infrastructure, and as a consequence - no modern housing development. ${ }^{1}$ [Czyński M. 2005]

- overpopulation of urban centers and rapid influx of people from the countryside (urbanization). Despite the blurring of the boundaries between living conditions in the countryside and in cities, many young people are looking for quick ways to become independent and find well-paid employment opportunities. It is connected with access to educational and entertainment facilities as well as to public utilities. It is estimated that by 2025 , as a result of urbanization, the urban population will account for about $63 \%$ of the total population.

- progressive urban globalization, manifesting in many areas of life. Globalization, apart from its positive influence on economic development, also takes on negative forms. In the conditions of rapid growth of jobs, the emergence of new housing estates should be perceived more often as multiplication of estate areas with only blocks of flats. Fast urban-forming processes are conducive to lowering the level of architectural culture of created objects and their monotony.

- uncontrolled urban sprawl as suburbanization and urban centers deurbanization. [Lorens 2005] The combination of these negative phenomena together with ensuring security in public places, places of residence and means of public transport, significantly affects building development ${ }^{2}$ and its harmonious perception. [Czarnecki 2012]

- gentrification (ex-urbanization), ie transformation and change of the character of a gentry as a result of the exchange of inhabitants of the district. In the modern world dominated by economy, most spatial processes have their own economic and social background. That is why the outflow of poorer people with a lower social status from the city centers is a tangible proof. Recently, most of the houses in the center of Barcelona have been bought by wealthy elites who have decided to make money on renting apartments to foreigners. Countering this phenomenon was even supported by the municipal authorities. The change in the character of central districts is connected with increasing the housing prices and the disappearance of social infrastructure facilities or small shops.

- concreting of significant areas of the city. Ensuring a balance between biologically active and built-up areas is most often guaranteed in the provisions of spatial development plans as local law documents. Spatial policy of many cities, according to research, is very diverse depending on the strategies and directions of future development. Some of them perceive their future as "Eco" cities, with sustainable urban transport ${ }^{3}$ and the creation of small green areas for leisure or integration. Building a sustainable living environment is based on "areas with specific features, identified and designated with the application of ecological and landscape ecology principles, whose main task is to regulate the functioning of the natural environment in the city." [Szulczewska, Kaliszuk 2005]

\section{Polish experience with the revitalisation process}

The term "revitalization" has permanently grown into the common vocabulary in Polish conditions. Revitalization has been described as a process of spatial, social and economic changes in degraded city districts, contributing to the improvement of the residents' quality of life of, restoring spatial order, economic recovery and

1 On the basis of research carried out in Vienna, 83 dangerous, risky and stressogenic places are: stops of public transport (29\%), underpasses (23\%), public garages (21\%), green areas and parks (18\%), entrances for buildings and staircases (9\%). At the same time, a list of avoided places was prepared (a defense strategy typical for women): collective transport stops (29\%), parks and green interiors (24\%), specific streets and squares (17\%), premises with alcohol distribution (10\%), underpasses (8\%), other places (7\%), narrow, poorly lit streets (6\%). p.254

2 "The features of spatial structures in the conditions of urban sprawl include, inter alia, the lack of hierarchy of space, in particular the communication system, the randomness of the structure of connections, usually the lack of separation of neighboring systems, chaotic development in both time and space, lack of devices and places of common use. The features of such structures influence the scope of social contacts and thus the possibilities of integration of the residents' communities, hindering navigational abilities, less efficient police operation in the vast areas of chaotic, often dispersed buildings, lack of desirable diversity or the coexistence of functions, lack of social infrastructure and many other phenomena." p.244

3 In Scandinavian cities, when creating a public space, it is aimed at making the bike the first choice of the inhabitant, the pedestrian traffic as the second, and the public transport the third. To achieve this, it is necessary to rebuild the space of many city centers, which in the case of historical buildings is not a simple task. 
rebuilding social ties. [Gaweł 2012] In order to emphasize the importance of the process for a specific place, many cities have decided to develop revitalization programs, which together with the local development plans were to give the transformed areas a priority and strategic character. Revitalization activities in Poland have created a new quality of shaping public space in cities. [Gaweł 2014]

The perception of revitalization in the conditions of the urban-forming process has positively changed the face of Polish cities during the period of economic transformation. Currently, the spatial aspect of the process is being lost, limiting its significance to renovation or rehabilitation of buildings. Poland was very keen on implementing revitalization programs, but the independent operator of the entire process decided on the success of their implementation. Most often it was an institution, in the form of a local group of professionals, responsible for creating a favorable climate of trust and credibility. The operator's duties include ensuring continuous information on the conditions of conducting the works (including the preparation of comprehensive documentation), negotiations with investors and institutions. [Skalski 1996]

In the period of economic transformation, our country continued to function in the conditions of a complicated housing situation related to the neglect of building renovations. The lack of balance between the demand over the supply of flats and the state's responsibility for the housing policy meant that there was much hope pinned on the process. [Zaniewska, Kowalewski, Thiel, Barek, 2008]

The revitalization of the old districts was supposed to generate many interdependent programs, consisting of [12]:

- construction of social and rotational flats for the less affluent,

- creating active forms of counteracting unemployment and social exclusion,

- protection of historical monuments and the cultural environment,

- creating accompanying technical and social infrastructure,

- implementation of new construction technologies,

- promoting environmental protection by saving energy.

The importance of the process of revitalization as a city-building tendency was proven with the significance of the central districts in the dynamics of the city development. The economic partners who wanted to use and develop the potential of these districts for contemporary life were expecting faster action. [Skalski 1996 p. 27] However, despite the assumptions made, social participation in the revitalization process was quite limited. It was often the result of dissatisfaction of residents of old housing resources with the change of their place of residence. Today, we have become accustomed to the new image of the renovated central urban spaces, often forgetting that they are the result of the revitalization process.

\section{The beginnings of tactical urbanisation}

People quickly understood that the rules of functioning of districts or housing estates created by the administrative authorities differ from their expectations and needs. Nowadays, changing cities function under conditions of climate change, a growing multinational population, changing economic situation or new technologies and building materials. In the face of many emerging problems, the everyday life of residents is becoming more and more of a challenge. Hence the creation of small local communities working to improve the living conditions and organization of the residential environment within public space. People were made aware that the city on its scale is not suited to the needs of people living in it.

The beginning of participation and social involvement in the process of city development and transformation go back to the mid-1970s in the USA, when W.H. Whyte organized the modest Project for Public Spaces PPS. [13] They aimed to create and support socially active spaces in New York, through so-called "placemaking". [Whyte 1980] The movement of people supporting such activities has grown so much that it was necessary to create a framework and develop the principles of project operation. It specified what should be done to create a socially active place. The collective way of using them determines the public character of urban spaces. [Palus, Zabawa - Krzypkowska 2015] That is why Whyte decided to define 11 principles of strength, which determine the creation of a socially active place. 
They are:

- community - is an expert - in other words, there is a potential in the community that needs to be discovered what is important for people needs to be established,

- create the place, not the project - that is, you should care about giving the characteristics of individual spaces, transform it for you and others,

- look for partners - who will help you in practical operation and not in the development of the project,

- you can see a lot by observing - watching how space works for people allows for future evolution and better management,

- have a vision, the space created should become an important place where people want to live in the future,

- start with: "lighter, faster, cheaper" - not everything comes quickly, sometimes we have to try many times to achieve the goal, but there are also simple things that can be quickly created and used,

- triangulation - finding a stimulus that will cause people to talk to each other as if they knew each other well, a triangle created - me - you - something that connects us in action,

- they always say "you cannot do it" - narrowing down your skills to avoid problems in creating people-friendly spaces,

- the form supports the function - although the design is important, the element will determine the vision of the form you need in a given place,

- money is not the problem - the cost is irrelevant compared to the benefits that we achieve by transforming the space,

you are never finished - openness to the need for change and flexibility of management builds large public spaces and big cities.

Promoting social activities to create a network of local public spaces is consistent with the principles of creating a contemporary and future sustainable city.

\section{Examples of tactical urbanism in selected cities}

Why urban planning? When defining the phenomenon, planners underlined that it is a process that had involved the community in a public project environment. It was planners and urban designers who saw the decisive role of social participation in achieving effective spatial cooperation. The adjective "tactical" refers to the unsanctioned nature of this process as a logical and deliberate approach to a predetermined goal. [ Lydon, Garcia 2015]

The statement that the pace of life in cities has been suddenly accelerated along with their spatial development seems to be a truism. We spend more and more time in traffic jams, shopping, at work or at the doctor's. We feel that the conditions of our functioning within public space are gradually deteriorating. Badly marked stops, dangerous underground passages, lack of car parks or poor street lighting are examples of poorly functioning places where the local community can influence the organization of public space within the living environment.

The most common example of activities within the framework of tactical urbanism projects is the modernization of local spaces, to adapt them to social needs, by:

- introduction of greater accessibility of public transport - e.g. free bicycles, scooters or buses, all in order to create healthy living conditions,

- creating a network of small gardens and pocket parks, most often in urban areas, where vegetables grow alongside trees and flowers,

- transformation of dangerous zones (districts) in cities, decorating them with balloons or murals, the appearance of people in these places, especially in the evening or at night, creates a sense of security,

- propagation of street art (e.g. decorating technical equipment with knitted fabrics, organizing street galleries),

- organizing small public spaces for leisure in empty, unoccupied places (open air cafes or summer cinema)

- creation of street furniture (e.g. furniture made from transport boxes and pallets),

- organizing markets and fairs, combined with the sale of handicrafts and clothes produced by the local community. 
Contemporary cities are experiencing increasingly serious problems that are the result of many overlapping factors functioning in the past.

From the 1970s, Medellin in Colombia was the headquarters of the largest drug cartel, supplying most of North and South America (over $90 \%$ of its production was destined for the US market). The city boasted of being a dangerous place where attacks, terrorism, kidnappings, corruption, extortion, racketeering and money laundering took place. For 20 years until the mid-1990s, the city was morally destroyed. Rebuilding the sense of security by changing the spatial structure in public places was very slow. Today, after another 20 years, the majority of citizens from the population of 2.2 million (agglomeration 3.7 million) still consider and view this city as dangerous. However, the created social groups working to improve the living conditions of residents operate very strongly and effectively. Increased safety in public transport (the only metro line in Colombia), "street pedagogues" working with youth groups at risk of exclusion or organize the activation of the unemployed. There are so many problems that there is no question of these groups replacing government or self-governing organizations. Spatial benefits from the implementation of tactical urbanism consist primarily of greater aestheticization of the city (graffiti disappears), translating into opening it for tourism. The increase in the affluence of citizens is reflected in the reconstruction of houses in the perennial pueblos, and the sense of security positively affects the development of local industry and services.
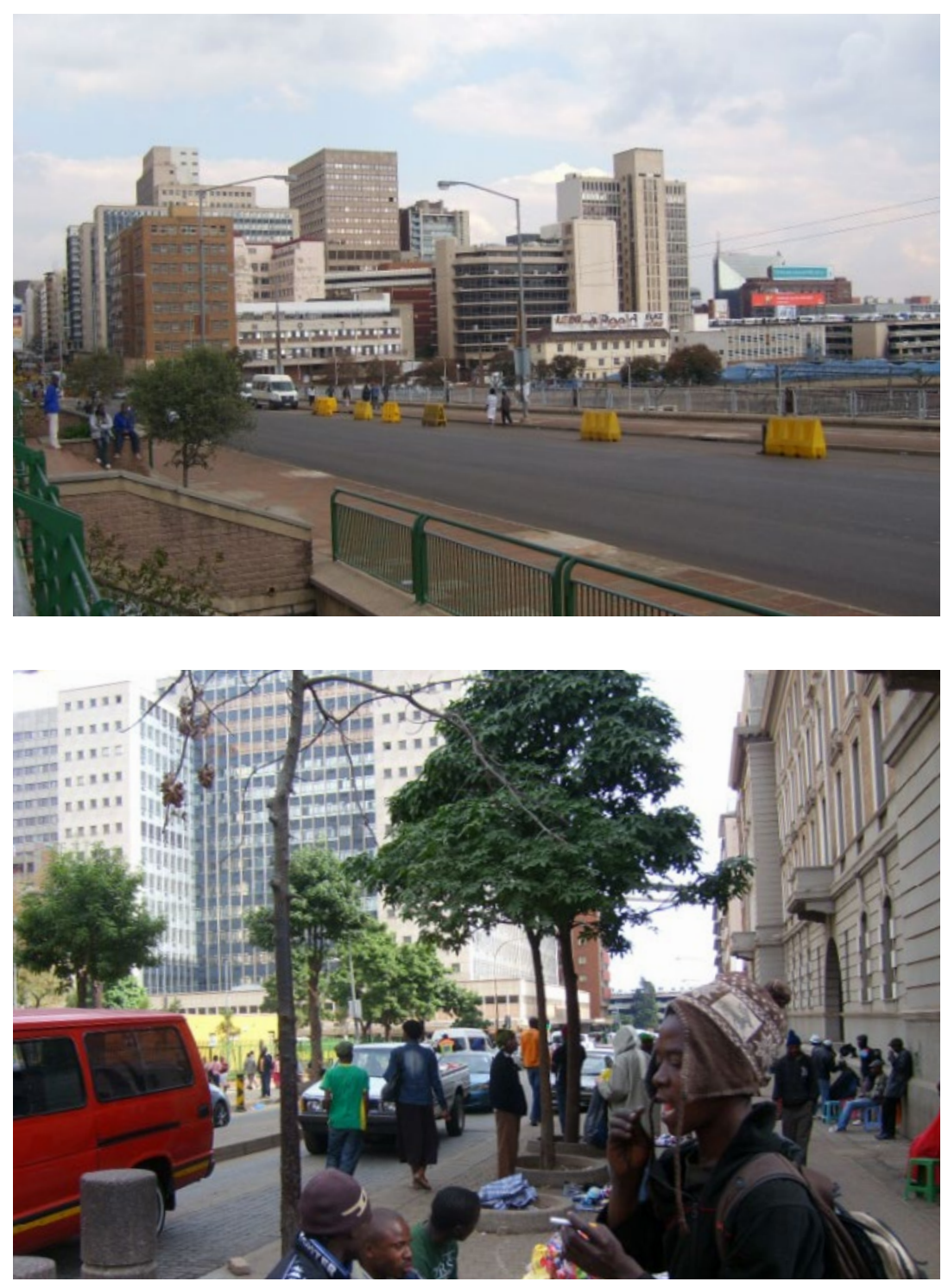

Fig. 1. Johannesburg downtown ceased to function as a business and commercial center, moving to Sandton or Rosebank. Fot. author.

Fig. 2. The crowded streets around Park Station in Johannesburg are infamous for dangerous places. Fot. author. 
Johannesburg is the largest agglomeration in the entire South Africa (about 4.5 million citizens) where the city itself has only 1 million. After the difficult years of the Apartheid (racial segregation system, where white people ruled the country; today they constitute only $14 \%$ of the city's population), the country cannot get rid of many accumulated problems. Joburg (as the locals call it) was considered to be the most beautiful city in Africa - today there are robberies, thefts and youth unemployment on the streets. There are no new investments in the center and the existing facilities are not renovated and technically exhausted. The authorities can not cope with the influx of poor people from neighboring countries, which forms peripheral ghettos with primitive substandard buildings. The invisible boundary created between the black and white population is constantly deepening.

Habits shape our choices, the quality of life depends on our sense of security. Many educated white residents leave the country, moving to the United States and Western Europe. That is why organized groups emerge that change the face of the city, helping both the white and the black population. Instead of graffiti, murals are created, and former "dangerous" places now function as playgrounds and community areas for residents.

Table 1. Comparison of activities effects in the basic groups, of process evaluation criteria. (Source: author)

\begin{tabular}{|c|c|c|c|}
\hline \multirow{2}{*}{ No } & Evaluation criteria & Tactical urbanism & Revitalization \\
\hline & 1 & 2 & 3 \\
\hline \multirow{4}{*}{1} & \multicolumn{3}{|c|}{ Architecture \& space } \\
\hline & creation of new public spaces & small spaces in residence areas & parks in the city \\
\hline & $\begin{array}{l}\text { attention to the aesthetics of } \\
\text { the buildings facades }\end{array}$ & $\begin{array}{l}\text { painting over graffiti and } \\
\text { murals }\end{array}$ & building renovations \\
\hline & $\begin{array}{l}\text { maintaining of the place } \\
\text { specificity }\end{array}$ & preservation of old buildings & protection of monuments \\
\hline \multirow{4}{*}{2} & \multicolumn{3}{|c|}{ Technique } \\
\hline & environmental protection & garbage sorting & $\begin{array}{c}\text { construction of modern garbage } \\
\text { dumps }\end{array}$ \\
\hline & $\begin{array}{l}\text { improvement of public } \\
\text { transport conditions }\end{array}$ & construction of bicycle routes & $\begin{array}{l}\text { construction and widening } \\
\text { streets }\end{array}$ \\
\hline & saving water & collecting rainwater for tanks & $\begin{array}{c}\text { construction waterworks of gray } \\
\text { water }\end{array}$ \\
\hline \multirow{4}{*}{3} & \multicolumn{3}{|c|}{ Social \& economy } \\
\hline & creation of the new jobs & $\begin{array}{l}\text { individual in the place of } \\
\text { residence }\end{array}$ & global in the industrial city \\
\hline & preventing social exclusion & $\begin{array}{c}\text { organization of courses and } \\
\text { trainings }\end{array}$ & $\begin{array}{c}\text { resettlement of families to other } \\
\text { homes }\end{array}$ \\
\hline & $\begin{array}{l}\text { shaping the social environment } \\
\text { of residents }\end{array}$ & $\begin{array}{c}\text { help for residents in renovating } \\
\text { their homes }\end{array}$ & construction of social houses \\
\hline
\end{tabular}

The huge tourist potential of the city as a transit destination starts bringing the intended benefits. It is known that the improvement will not happen overnight, but the developing structures of the organized community are able to counteract negative phenomena. The most positive examples of the activities of organized social structures in the framework of tactical urbanism are recorded in the USA and Canada. Both countries with a high level of democratic culture have well organized societies which can come together and work in the name of superior goals. In Europe, the first organized social structures transforming urban space were created in Spain and France. 


\section{Conclusions}

The choice of an appropriate method of action depends on many factors (and above all on the degree of degradation of the built environment), which results in the transformation of urban space, including the actions of residents.

1. Both processes are not mutually exclusive, they are implemented in completely different conditions of spatial and social degradation of cities. Differences in the methods of operation rely on different levels of functioning: revitalization - as a top-down, strategic process and tactical urbanism - as a bottom-up, operational process. However, their success is determined by the residents striving to adapt the public space to their needs.

2. Revitalization as a phenomenon known and described in many publications has become the main process of renewal of Polish cities. Its popularity is associated primarily with the possibility of obtaining significant EU funds, intended to finance the implementation of this process.

3. Tactical urbanism has a chance of success thanks to the organization of local social environments and groups of inhabitants. The condition for the success of these activities is to implement them through comprehensive and simultaneous action. Their result is the improvement of living conditions and improvement of the quality of the living environment within the street or district.

4. Being independent of external financing (top-down) should be seen as an added value of activities in tactical urbanism. The organization of local residents' environments through education and work for others is a measurable incentive to develop initiatives within neighboring urban structures.

5. Counteracting the degradation of the built environment of cities significantly affects the sense of security and the degree of social integration of residents. This degree becomes very important in the case of a multinational social group, creating a local environment of residents of housing estates and blocks of flats.

6. The inhabitants of a given place should decide about the choice of an appropriate way to improve living conditions and adjust public space. Both revitalization and tactical urbanism are examples of actions leading to the creation of a sustainable city, worthy of the contemporary times.

Table 2. Processes of revitalization and tactical urbanism - similarities and differences. (Source: author)

\begin{tabular}{|c|c|c|c|c|}
\hline & Process & Tactical urbanism & $\begin{array}{l}\text { Micro process } \\
\text { revitalization }\end{array}$ & Revitalization \\
\hline & 1 & 2 & 3 & 4 \\
\hline 1 & Action method & operation & operation & strategy \\
\hline 2 & Financing & private & private $\&$ public & public \\
\hline 3 & Area & $\begin{array}{l}\text { housing district } \\
\text { housing estate } \\
\text { street }\end{array}$ & $\begin{array}{l}\text { housing district } \\
\text { housing estate } \\
\text { street }\end{array}$ & $\begin{array}{l}\text { city } \\
\text { town } \\
\text { region }\end{array}$ \\
\hline 4 & Management & bottom-up & top-down & top-down \\
\hline 5 & Activity effects & local & $\begin{array}{c}\text { local } \\
\text { citywide }\end{array}$ & $\begin{array}{l}\text { citywide } \\
\text { regional }\end{array}$ \\
\hline 6 & $\begin{array}{c}\text { Participants } \\
\text { (members) of } \\
\text { process }\end{array}$ & inhabitats & $\begin{array}{c}\text { inhabitats } \\
\text { social organizations }\end{array}$ & $\begin{array}{c}\text { inhabitats } \\
\text { social organizations }\end{array}$ \\
\hline
\end{tabular}




\section{Urbanistyka taktyczna czy rewitalizacja, miasto na miarę ludzi}

Streszczenie: Żyjemy w warunkach nieustannie zmieniających sie miast. Przeobrażenia przestrzenne, dokonujące się na naszych oczach, dotyczą zarówno starych dzielnic, osiedli mieszkaniowych jak również infrastruktury technicznej czy terenów niezurbanizowanych. Bardzo istotne znaczenie dla powodzenia całego procesu zmian ma udział organizacji społecznych i samych mieszkańców. W Polsce do tej pory najbardziej popularnym procesem odnowy przestrzeni była rewitalizacja. W wielu zdegradowanych miastach świata w ostatnich latach wyjątkowo popularnym i efektywnym procesem przekształceń przestrzeni publicznej, okazał się projekt urbanistyki taktycznej. Przedmiotowy artykuł jest próbą porównania obydwu procesów w wybranych miastach, z uwzględnieniem korzyści wynikających z wdrażania ich w życie.

Słowa kluczowe: urbanistyka taktyczna, rewitalizacja miasta, miasto, ludzie 